\title{
OUR MONUMENTS TO GLORIOUS DEFEAT: SOCIALIST MEMORIAL ART IN BRITAIN
}

OWEN HATHERLEY

United Kingdom, SE5 8RF London, Camberwell

Grove 94

owenhatherley@gmail.com

iD orcid.org/0000-0002-2843-4236
DOI: $10.17234 /$ SEC.29.7

Preliminary communication Received: 24. 5. 2017.

Accepted: 12.9. 2017.

This article is an open access article distributed under the terms and conditions of the CC BYNC-ND 4.0 license.

Britain is the one major European country never to have had a numerically significant Communist movement, with Marxism generally limited either to far-left enclaves in Wales and Scotland, Labour Party entryism or, most commonly, academia. However, the Labour movement at its more radical edges has produced numerous monuments, memorials and spaces, littered around urban and even rural Britain. Typically, they are monuments to defeat, given the lack of any hegemonic socialism in Britain. They are also unusually figurative for 20th century public sculpture, suggesting a perhaps unexpected traditionalism, not usually considered to be the case for the 'west', in the Cold War polarities often used to analyse monumental artworks. This paper will discuss these narratives of heroic failure as expressed in mosaics, murals, sculptures and plaques in South Wales, the north of England and London as attempts to answer the question of what socialist memorials are like in a country without even historical socialism.

Keywords: Britain, Marxism, Social Democracy, Urbanism, Nostalgia, Sculpture, Architecture

In Highgate Cemetery, North London, is one of the largest Soviet memorials in any country that has not been occupied at any point by the Red Army. Hewn out of black granite to the designs of the realist sculptor Lawrence Bradshaw and unveiled in 1956 by the leader of the Communist Party of Great Britain Harry Pollitt, and swiftly visited by its principal sponsors, Nikita Khrushchev and Nikolai Bulganin. It is by far the largest monument in the most famous burial ground in Britain, dwarfing, as it is intended to, both the elaborately carved tombs of Victorian notables and the humble stone slabs on the graves of lesser figures. Marx's gigantic, fuzzy-whiskered head, sculpted with almost cartoonish attention to detail, glowers over a heavy 
plinth bearing the words 'WORKERS OF ALL LANDS UNITE. KARL MARX. THE PHILOSOPHERS HAVE ONLY INTERPRETED THE WORLD, THE POINT HOWEVER IS TO CHANGE IT' and two granite wreaths. Inset into this, is the original gravestone of the family Marx, a $19^{\text {th }}$ century group containing father Karl, wife Jenny, daughter Eleanor, grandson Harry and housekeeper Helene. You can easily see that if this were just one of the many stones scattered around Highgate, it would fail to have the sort of imposing, pathos-ridden effect that Soviet sculptors and town planners considered to be so important to the transmission of socialist consciousness. In order to redress this indignity, the Union of Soviet Socialist Republics specifically paid for and commissioned the sort of monument they thought the corpse of Karl Marx deserved. The result is strikingly alien in the British landscape, the sort of giant bust to be expected more in Chemnitz or UlanUde, an extreme image of the importance of the Great Man for certain forms of self-professed Communism. Within this is the paradox. Marx worked here and died here partly, to be sure, because of Victorian Britain's relaxed asylum policies, but also because here was the world's most advanced capitalism, whose totally urban, industrial and hugely populous proletariat should, in his theory, have been the most committed to Communism. And yet, Russians had to pay for a redesign of his grave, because the British working class movement did not consider it worthy of their efforts.

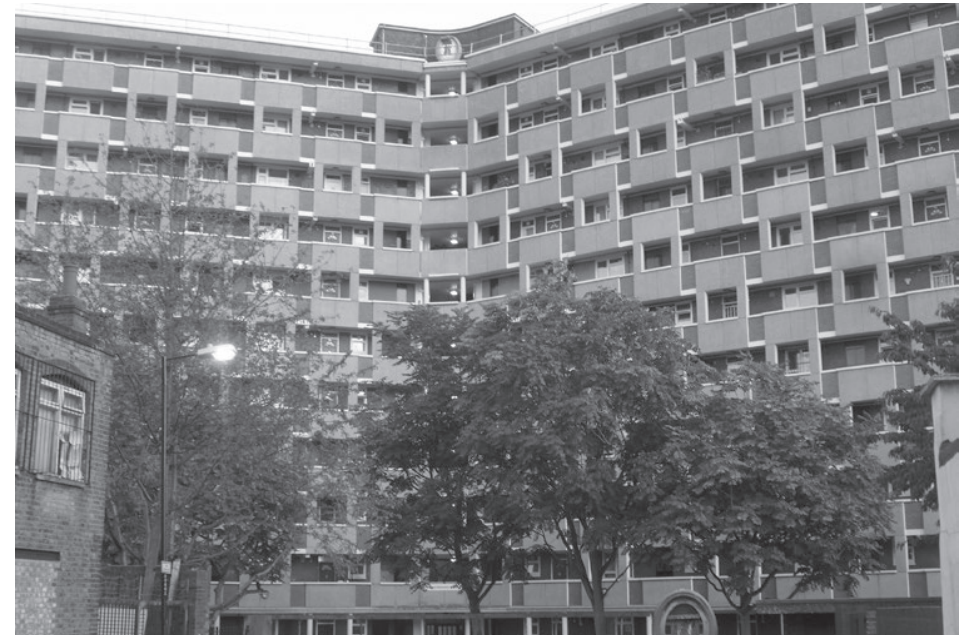

Picture 1: Dorset Estate, London, taken by author, June 2012

https://www.flickr.com/photos/8971770@N06/6151582700/in/album-72157627679427286/ 


\section{SOCIALIST MONUMENTS WITHOUT SOCIALISM}

It is proverbial that Britain is the major Western European country with the weakest Communist tradition. Not only did it not have the mass Communist Party that could be found at various points of the $20^{\text {th }}$ century in France, Spain, Portugal, Germany, Italy, Greece, Finland, it also lacked a major Social Democratic Party in the sense of a centre-left party which had emerged out of the schisms of $19^{\text {th }}$ and early $20^{\text {th }}$ century Marxism, as was the case with the mass Social Democratic Parties of Sweden, the Netherlands, Austria, Germany, France, Spain, and so forth. Politically it was something more mid-Atlantic, as unlike the United States it did have a mass labour party, committed to working class representation, and between 1919 and 1994 to some form of socialism, at least in the party statutes. However, the revolutionary Marxist tradition has been weak in terms of Party politics. The Communist Party of Great Britain has had a grand total of four Members of Parliament, and a maximum of two at any given point - that being the 1945-1950 Parliament, where Communists were elected for seats in East London and the Fife coalfields in Scotland. The contributions made by the CPGB in British public life have been in unexpected fields. One of these was historical research - the famed Communist Party Historians Group, containing the talents of Christopher Hill, Eric Hobsbawm, E. P. Thompson, and later Raphael Samuel and Raymond Williams, most of whom broke with the Party over the Soviet invasion of Hungary in $1956 .{ }^{1}$ The other, peculiarly, was the partial creation of New Labour, via the Party journal Marxism Today, where Stuart Hall, Martin Jacques and Beatrix Campbell helped shift social democracy away from even the most rhetorical commitment to socialism. ${ }^{2}$ Both of these decisive Communist interventions were intellectual, rather than political, fittingly given that the Labour

\footnotetext{
${ }^{1}$ Fittingly, one of the crucial debates was over the problem of why the Marxist tradition in Britain was so weak. See the debates later collected in E. P. Thompson, The Poverty of Theory (New York: Monthly Review, 2008) and Perry Anderson, English Questions (London: Verso, 1992).

${ }^{2}$ The most eloquent statements of this group can be found in Stuart Hall, The Hard Road to Renewal (London: Verso, 1988). For an equally eloquent attack, see Ralph Miliband, "The New Revisionism in Britain". New Left Review, vol. I/150 (March-April 1985):5-26. The author, ironically enough, was the father of two particularly centrist Labour politicians.
} 
tradition was never noted for its intellectual reach. ${ }^{3}$ Aside from small 'little Moscows' in mining areas (in Durham, Fife and South Wales) or in Greater Glasgow (where Jimmy Reid led the CPGB's last serious electoral challenge in the early '70s), its political reach was minimal. ${ }^{4}$

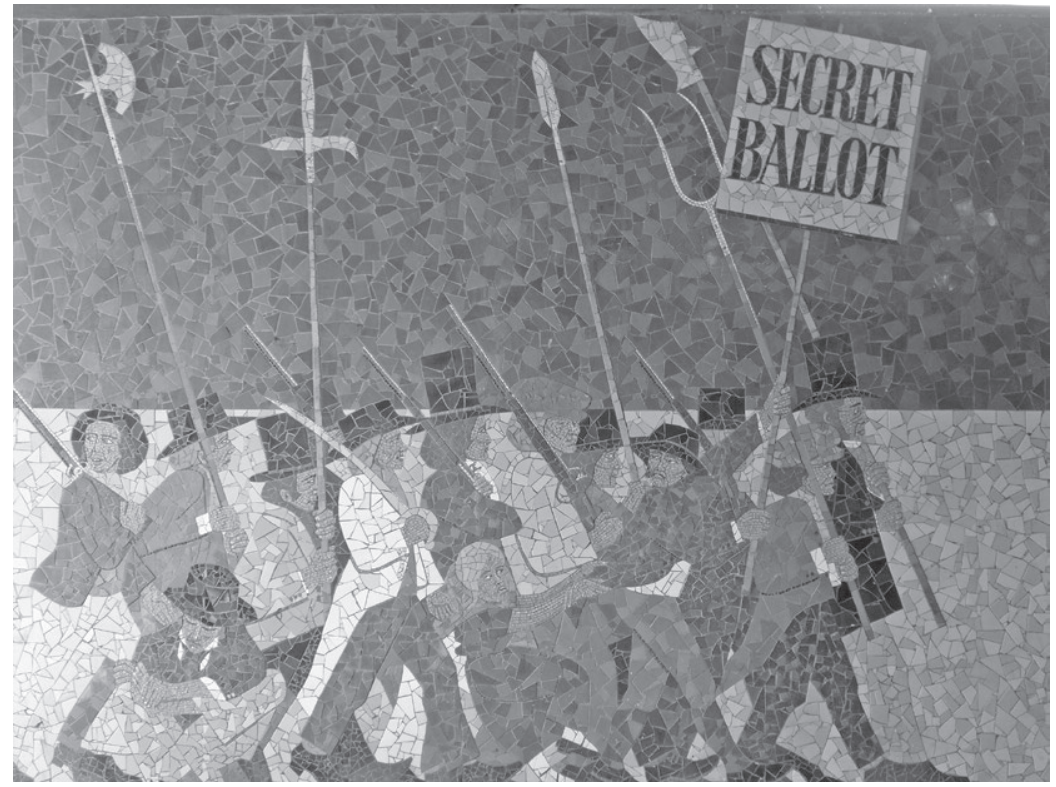

Picture 2: Chartist Mural, Newport, taken by author, June 2012 https://www.flickr.com/photos/8971770@N06/7604612396/in/ album-72157627155942512/

At this distance, all this may appear as a deeply academic debate, as the politics - and the decline - of the British Labour Party in the $21^{\text {st }}$ century has been very closely comparable to the German SPD or the French PS, irrespective of their different historical roots. However, the European country in which radical forms of socialism have apparently been weakest can precisely because of this form an interesting contrast to

\footnotetext{
${ }^{3}$ Hence the exasperated tone that ensues when leftist intellectuals have tried to analyse 'Labourism' - see particularly Gregory Elliott's Labourism and the English Genius (London: Verso, 1993).

${ }^{4}$ On the distinctive culture of these red bases, see Stuart Macintyre, Little Moscows (London: Croon Helm, 1980).
} 
states which have either had some sort of experience in Soviet-influenced 'real socialism', as in Central-Eastern Europe, or in the partly hegemonic social democracies of, for instance, Scandinavia or Austria. ${ }^{5}$ That is: what is a socialist memorial art like in a country where socialists have very seldom held secure state power? This question is especially interesting in the light of the fact that one of the most notable aspects of the British far-left is its early connection with aesthetics. On the one hand, the more conservative part of the Labour movement, around the explicitly patrician Fabian Society, included major writers such as George Bernard Shaw and, for a time, H. G. Wells, but on the other, one of the many organisations that later went to form Britain's stillborn Communist Party was the Social Democratic Federation, which included among its members William Morris, whose opposition to capitalism on the basis of the ugliness created by drudgery of its work was combined with a commitment to revolution derived from his reading of Marx. ${ }^{6}$ Because of this, socialism and aesthetics have often gone hand-in-hand, with architecture and applied art often being both politicised and (aesthetically) traditional. Another Social Democratic Federation member, Raymond Unwin, became a hugely influential planner of 'garden cities', built usually by bourgeois philanthropists or 'municipal socialist' local authorities. There was material to build on here, however unpromising the political context.

So in this paper, we will explore some of the explicitly socialist artworks that have emerged in public space in the context of $20^{\text {th }}$ century British capitalism, and we will treat them in chronological order - not of their production, but of the events about which they can provide an oblique chronology. Methodologically, this paper is a work of Political Aesthetics, approaching the surviving monuments both as historical objects and as the focus of political contest, caught dialectically between their presence as artworks and their overt ideological content. It is largely limited to the

\footnotetext{
${ }^{5}$ Goran Therborn's recent Cities of Power (London: Verso, 2017) contains a useful chapter on the place of explicitly socialist iconography in the public spaces of Vienna, Oslo and Stockholm in particular.

${ }^{6}$ On Morris's socialism, see his Useful Workv. Useless Toil (London: Penguin, 2008), or E. P. Thompson's biography, William Morris, From Romantic to Revolutionary (Pontypool: Merlin, 1982).
} 


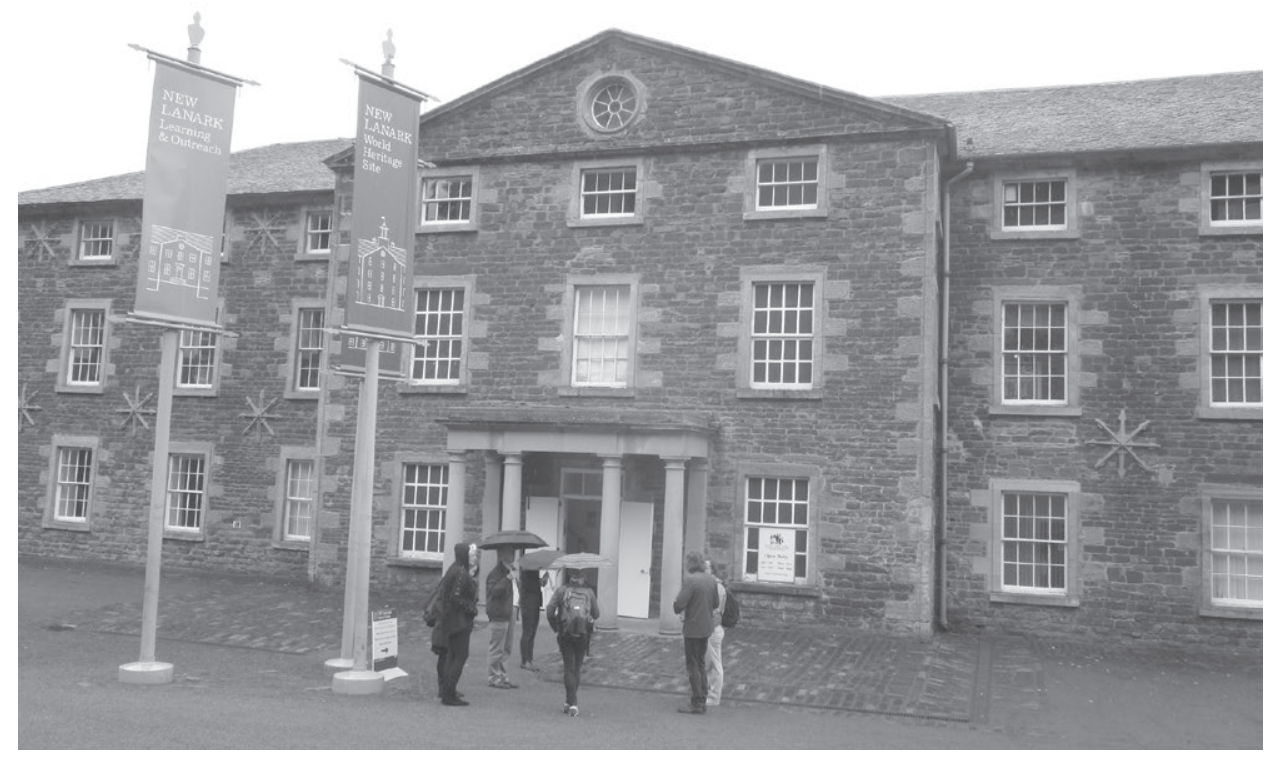

Picture 3: Institute for the Formation of Character, New Lanark, taken by author, June 2012

https://www.flickr.com/photos/8971770@,N06/21599947530/in/album-72157659220962071/ question of the production, and to a lesser degree, the reception and use, of these monuments. Most of those described have not given rise to any public practices around them - marches, rallies and similarly overtly political acts of remembrance have been limited to the regular meetings at our first example (the grave of Karl Marx in north London) and to the various monumental spaces of the 'Tolpuddle Martyrs', in rural south-west England. There is no overt engagement with recent work on memory and socialism by such as Victor Buchli, Svetlana Boym and Charity Scribner, largely because this has focused on the Cold War's 'East', where the monumental spaces were linked with state power rather than a largely oppositional force - tough their sophisticated and open-ended approach to the intersections of ideology, everyday life and aesthetics has undoubtedly been of some influence. ${ }^{7}$ The term 'socialism' is used in a much more expansive manner than what is

${ }^{7}$ Charity Scribner, Requiem for Communism (Cambridge: MIT, 2005), Victor Buchli, An Archaeology of Socialism (Oxford: Berg, 2000), Svetlana Boym, The Future of Nostalgia (New York: Basic, 2002). 
in my view an unfortunate limiting of its use to the state socialist regimes set up either directly by or under the heavy influence of the Soviet Union. Instead, I use a definition similar to those of Zygmunt Bauman or G. A. Cohen, ${ }^{8}$ of socialism as a global movement that encompasses within it social democracy, labourism, revolutionary socialism, state socialism, libertarian Communism and the labour movement in general - as opposed to socialism as a supposedly realised (and then abandoned) reality. This is because, as will be clear, an underlying argument of this paper is that the various material practices thrown up by the 'softer' electoral socialisms - here, British social democracy and its labour movement - have been subject to neglect, both in the academia and, as we will see, within British public space.

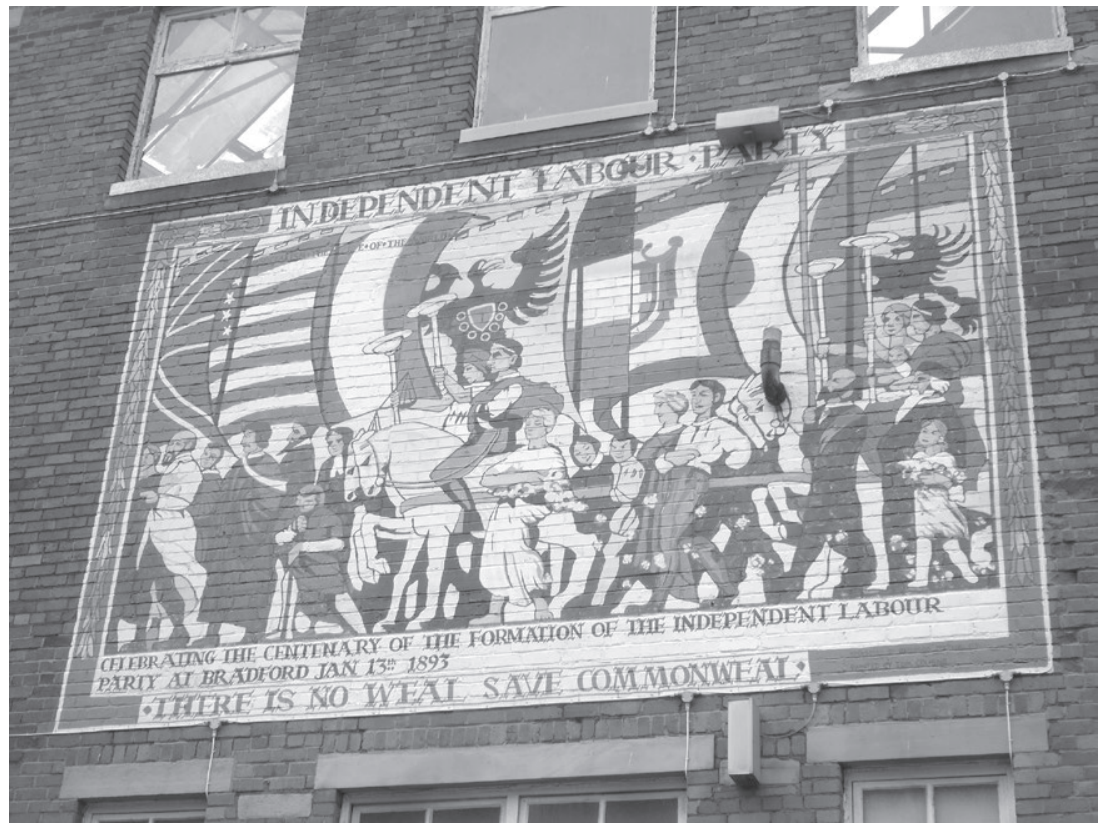

Picture 4: Mural on the site of the foundation of the Independent Labour Party, Bradford, taken by author, June 2012 https://www.flickr.com/photos/8971770@N06/6972708972/in/ album-72157629912054777/

${ }^{8}$ Zygmunt Bauman, Socialism - the Active Utopia (Abingdon: Routledge, 2011), Gerald A. Cohen, Why Not Socialism (Princeton: Princeton University Press, 2009). 


\section{UTOPIANS AND MARTYRS}

The history of the British labour movement can reach as far back into the modern era as the analyst prefers, right back to the early Communists of the 'Diggers', the most radical of the many sects thrown up in the 1640 by the English Civil War. But in terms of the socialist movement that emerged in the $20^{\text {th }}$ century to sporadically govern the UK, the most important precursor is the Utopian Socialism of the textile mill-owner Robert Owen. In the secluded factory complex of New Lanark, just outside Glasgow, founded at the turn of the $19^{\text {th }}$ century, Owen first exploited the recentlyrural workforce in the customary manner, but then went on to experiment with educating the workers, eliminating child labour, instituting inequality of the sexes, and equally splitting the fruits of their labour. ${ }^{9}$ Although the experiment was limited to one very small village, and although there was nothing in the way of workers control, this was the first example of selfconscious socialism in British public life. Although he initially attempted to interest the British ruling class in his discovery of a 'new view of society', in which industry would destroy inequality rather than exacerbate it (if correctly managed, of course), Owen became perhaps unexpectedly sympathetic to the nascent British trade union movement, and its radical fringe - with its commitment to not merely alleviating existing society, but reconstructing it anew - was highly influenced by Owen's ideas.

Because of this, and because of its historical novelty as an early example of both socialism and industrial capitalism, New Lanark is a World Heritage Site, and time has softened to some degree the novelty of these monumental, stark mills and tenements - being surrounded by forests, alongside a waterfall, it is almost picturesque. The complex nature of Owen's politics is presented in an 'experience', built in the 1990s, where the visitor mounts a suspended little pod, as in a ghost train, which then carries them through a partly holographic exhibition on the town as viewed

\footnotetext{
${ }^{9}$ See Robert Owen, A New View of Society and Other Writings (London: Penguin, 1991), and for a recent, somewhat hostile account of New Lanark, Jacqueline Yallop, Dreamstreets - a Journey through Britain's Village Utopias (London: Random House, 2015), and on the more radical later moment of 'Owenism', Barbara Taylor, Eve and the New Jerusalem - Socialism and Feminism in the $19^{\text {th }}$ Century (London: Virago, 1983).
} 


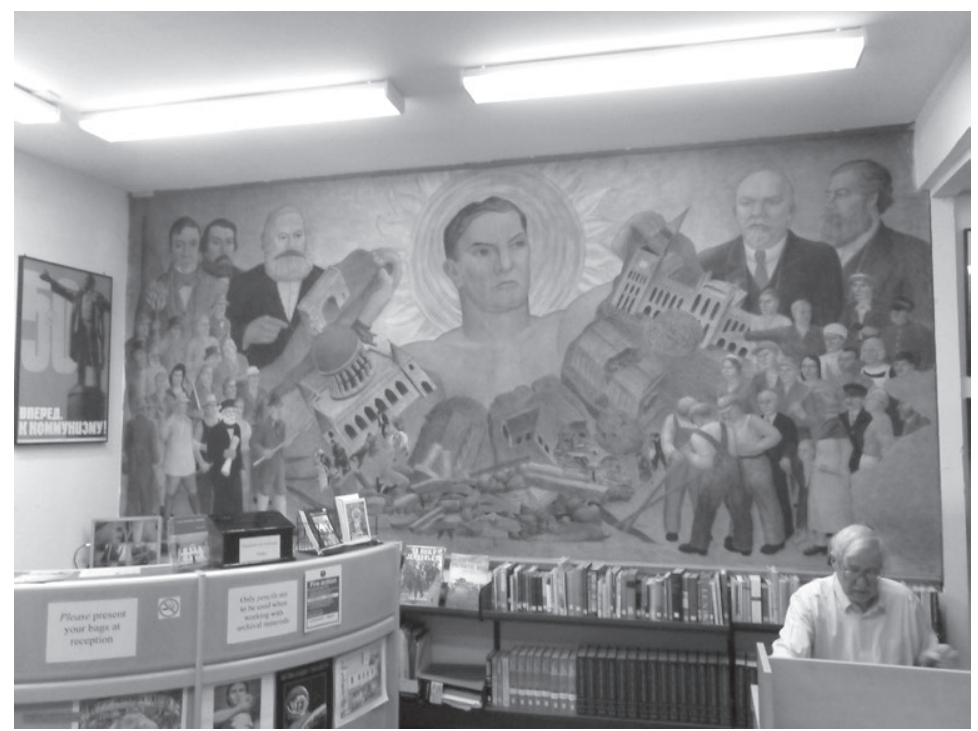

Picture 5: Mural, Marx Memorial Library, London, taken by author, June 2012 https://www.flickr.com/photos/8971770@N06/5844984637/in/ album-72157626865135313/

by one of the small Scottish children raised under Owen's benevolent eye (she notes the incongruous fact that Owen, despite his ideas, lives in the biggest house in town). It is quite typical of the more ambitious of the sort of exhibits which were opened in formerly industrial towns, its greater technical means probably a consequence of UNESCO's patronage. The town is a museum of itself, and given its geographical position and tiny size, it couldn't really have been anything else; but in the process, the ideas behind the foundation of radical socialism in Britain are necessarily heavily tamed. They're a matter for giggling - the fact that the workers who were educated well into adult life in the 'Institute for the Formation of Character' wore togas, not suitable weather for the Clydeside climate, being a particular object of hilarity. In New Lanark, Utopian socialism is just another aspect of heritage culture, this time with added eccentricity.

Ironically, the co-operatives set up in the north of England by 'Owenites' from the 1850s onwards have long had a much stronger presence in the built landscape, commissioning a great deal of impressive civic architecture in the form of often strongly modernist department stores, offices and warehouses right up to the 21 st century. However, their only 
monumental presence is a clumsy statue of Owen outside the Manchester headquarters of their current incarnation, the Co-Operative Group, eviscerated of its final social aspirations in the aftermath of the 2008 crash. The trade unions, always a much more massive and fundamental part of the labour movement, trace themselves to the 'unlawful oaths' and illegal 'combinations' embarked upon by rural labourers in the village of Tolpuddle, in the (now) affluent southwestern English county of Dorset. This was the home of the Tolpuddle Martyrs, four farm labourers who formed an early trade union here in 1832, and faced deportation to Australia for doing so. In the town itself, a socialist rally and music festival takes place every summer, and there are some small monuments to the 'Martyrs'. In one London housing estate, you can find each of these forefathers of British socialism given their due, at least in the naming of buildings. The Dorset Estate, built to the designs of Skinner, Bailey and Lubetkin (of whom more later) in the late $1950 \mathrm{~s}$, is a peculiar combination of decorative detail - indebted both to the Caucasian carpets one of the architects remembered from his childhood, and more debatably, to the ornamental tradition of radical design inherited from William Morris, a firm enemy of the stark aesthetics of machine production. The blocks of this estate, so-named because of the county where the martyrs lived, are named either after Tolpuddle trade unionists, or after Owen himself. ${ }^{10}$ Their monumental arrangement, generous public spaces and public buildings, are an unusually explicit attempt to create a socialist space in a British city.

Marx and Engels put many of their hopes in the 'Chartist' movement that rose to prominence in the mid- $19^{\text {th }}$ century. It was named after the People's Charter, with its call for universal (male) suffrage and a range of other democratising demands. A largely working class movement which was particularly strong among the factory proletariat in the north of England and South Wales. The movement was the best plausible bet for leading a revolution, at its height, and it resulted in an armed uprising led by workers the mining and metallurgy industries of South Wales, culminating in an insurrection in the city of Newport. This was, until recently,

${ }^{10}$ For a more detailed analysis of these, see my Militant Modernism (Winchester: Zero Books, 2009). 
remembered in a series of mosaic panels underneath a 1970 s retail precinct. That unprepossessing description gives little sense of just what remarkable mosaics these were. Designed by Kenneth Budd in 1978, they retain much more of a sense of revolutionary fervour than the staid heritage gestures so common to monuments of the British labour movement. Bright, dramatic (and armed) marching figures in hats and coats, arranged in semi-geometric groups but with closely detailed faces closer to popular caricature carry the banners of the Charter, and march, doomed, towards rifle fire. It is not an image of a successful revolution, but in its wit and visual imagination The murals were demolished despite widespread popular protest in 2013,

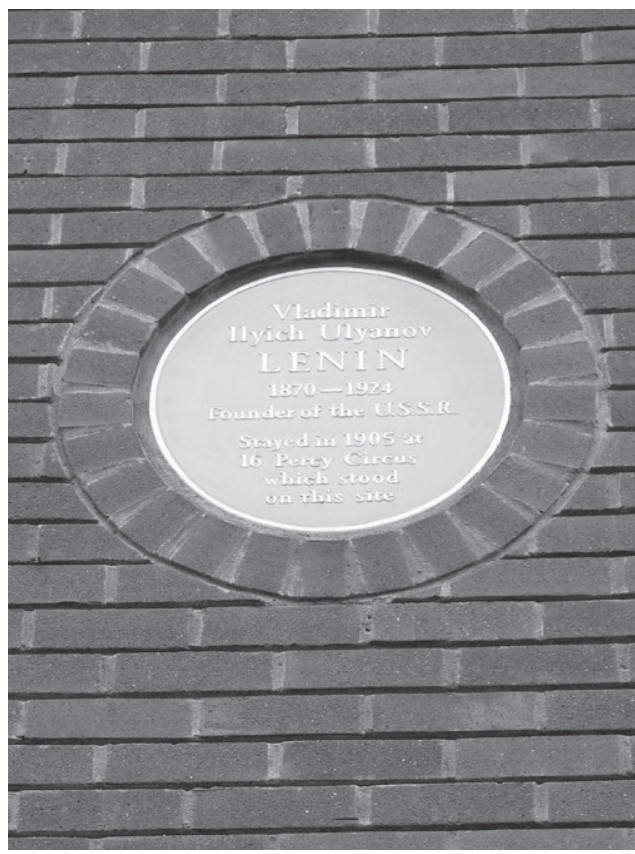

Picture 6: Lenin Plaque, Percy Circus, London, taken by author, June 2012 https://www.flickr.com/ photos/8971770@,N06/34183274305/in/ album-72157626865135313/ to be replaced with a new shopping mall; ${ }^{11}$ they had failed to be listed by Cadw, the Welsh Heritage body, despite an application for them to be moved elsewhere in the city. Given this is still one of the poorest cities in Britain, it is not altogether surprising that it was not considered useful to remind residents of violent insurrection.

\section{THE CASE OF THE DISAPPEARING LENIN}

The Communist Party, despite its sporadic and deeply geographically limited bases in some scattered coalfields, never managed to control any municipality in the long-term, so their legacy in terms of monuments is necessarily all-but-non-existent. The exceptions include two murals which,

${ }^{11}$ See Dawn Foster, "The Writing on the Wall”. New Statesman, May 16, 2013. 
rather tellingly, are inside buildings. The earliest is part of somewhere that is particularly interesting for our purposes - the Marx Memorial Library, in Clerkenwell, London. Situated on Clerkenwell Green, which is according to the perhaps unreliable source of the prolific biographer and novelist Peter Ackroyd ${ }^{12}$ the single site in Europe that has seen more civil unrest than any other. The building is a Georgian, classical palazzo that was for much of the early $20^{\text {th }}$ century a radical printing press; Lenin used one of the back-rooms to edit Iskra during his London exile. Controlled by the Communist Party of Great Britain from the 1920s onwards, it is among the permanent buildings most associated with British Communism - the other two, the nearby printworks for their paper, the Daily Worker, designed by the great Hungarian modernist Erno Goldfinger, and the $18^{\text {th }}$ century office refurbished by Goldfinger in Covent Garden to serve as the Party headquarters, have been either destroyed or remodelled to the point of being unrecognisable. The Marx Memorial Library, however, survives, despite the Soviet funding that once kept it afloat having long since disappeared. One consequence of this is that it contains two particularly intriguing memorial spaces. The room where Lenin edited Iskra contains an authentic Communist cult object in the form of Lenin's own desk, and is surrounded by memorials, maps and portraits donated by the USSR and its satellites over the years, making this small London room into a tiny cousin of the Lenin memorial spaces of Ulyanovsk, Razliv, Gorki Leninskie, et al.

Better known to Londoners, and to users of the Library, is the mural that takes up the blank space behind the librarian's desk in the main reading room - 'the Worker of the Future Upsetting the Economic Chaos of the Present', as it is known. Painted by the aristocratic socialist painter Viscount ('Jock') Hastings, and opened to the public in 1934, although it is clearly figurative and realist, it is indebted less to Soviet socialist realists like Gerasimov or Brodsky, and more to the Mexican Muralists (Hastings had worked with Diego Rivera), sharing their favouring of vertiginous perspective, peasant simplicity and cartoonish exaggeration. If the style is a somewhat goofy translation of Rivera or Siqueiros to less sunny climes, its imagery and subject matter are an attempt at English adaptation. At the

${ }^{12}$ See Peter Ackroyd, London: A Biography (London: Chatto and Windus, 2000). 
centre of the mural is a square-jawed, shirtless worker, with a sun rising above his head, as if he were a pagan deity. Flanking him on one side, are Engels, Marx and Robert Owen, and on the other side, Lenin and William Morris - all of them, aside from their contribution to socialism as theory and practice, residents of the United Kingdom at one time or another; and below them, are the massing workers of Britain, of various eras and ages. But below the worker, you can see the symbols of British power, both church and state, being torn asunder, with St Paul's and the Houses of Parliament being wrenched from the earth as if by an earthquake. It is a fascinating image at least partly for its uniqueness. Although the subject matter is mostly British, it is very transparently an importation of a conception of revolutionary change that has seldom been shared by the British proletariat.

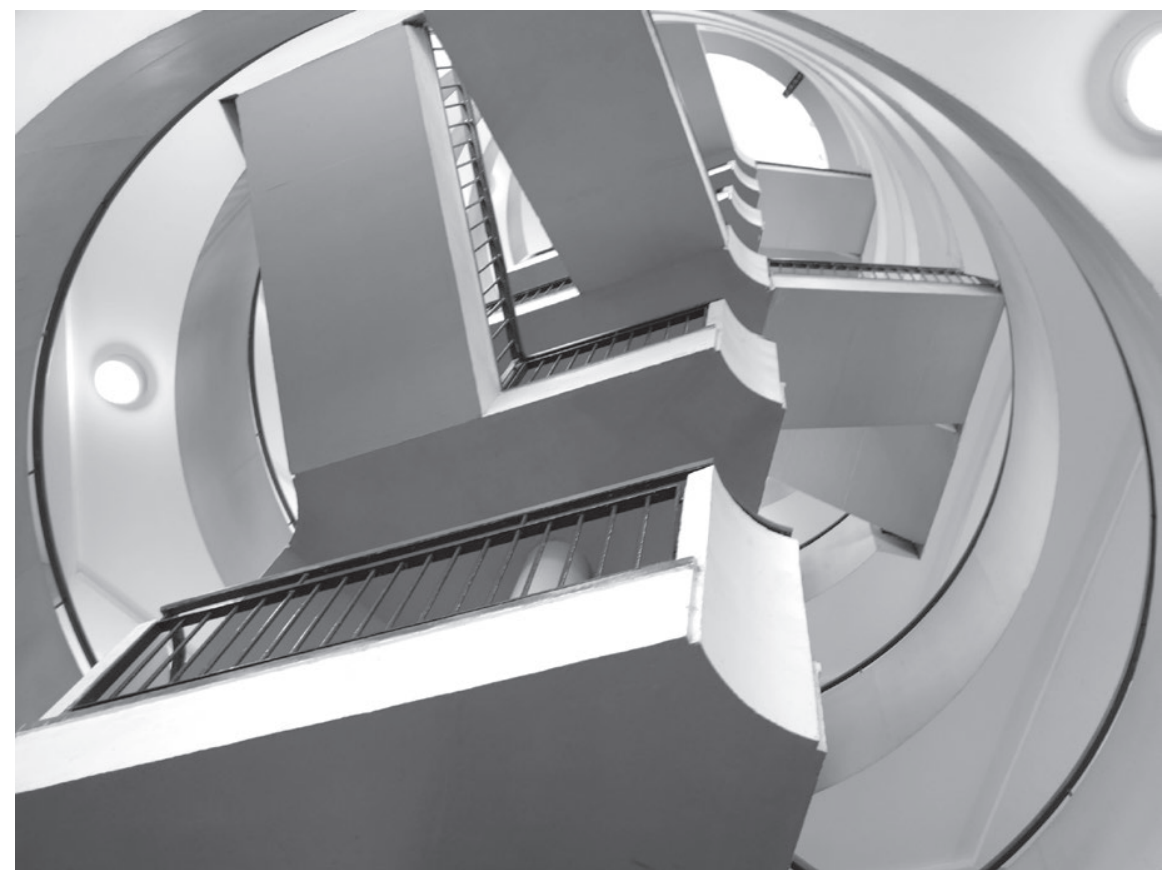

Picture 7: Bevin, formerly Lenin, Court, London, taken by author, June 2012 https://www.flickr.com/photos/8971770@N06/34052237231/in/ album-72157626865135313/ 
Nothing similar would be created until very different political circumstances in the 1980s, when the New Left inside and outside of the Labour Party became more inclined to celebrate the alternatives to a narrowly conceived parliamentary social democracy. One of those most frequently held up as a road not taken is the event in Glasgow in the aftermath of the First World War - 'Red Clydeside', when a series of rent strikes and workers' agitation led to a January 1919 rally in Glasgow which was suppressed with tanks. This forms the centrepiece of a series of murals painted in 1987 by Ken Currie on the dome of the People's Palace, a late Victorian municipal public hall, in Glasgow Green. The Palace and the artist provide a detailed key to understanding the mural on their website, ${ }^{13}$ an indication of just how literal a kind of figurative representation this is - you are informed what part of the mural refers to the Weaver's Strike of 1787, what refers to the Great Reform Bill, what refers to unemployment and the International Brigades in the 1930s, and what refers to the occupations of shipyards by Communists like Jimmy Reid in the early 1970s and the Miners Strike of the mid-1980s. At the heart of it all is the moment of Red Clydeside, and presiding over it, the Scottish Communist leader and Commissar John Maclean, the most committed among Glasgow's socialist leaders to violent revolution. What is notable about this mural, aside from its Gothic fervour (much closer to the Caravaggio-like darkness of Siqueiros than the brighter style of Rivera and Viscount Hastings), is just how much of it deals with failure, with battles fought and lost - and it is this, as much (or more) than the style, that makes it so conspicuously different to ostensibly similar murals in 'real socialist' countries, aside from their very different use in terms of state power. In the 1980s, socialists in Britain became particularly interested in their own history, to the point almost of coming across like a conservation or heritage movement. This is best understood as a consolatory approach to the historic defeat of the labour movement under Margaret Thatcher, culminating in the violent, underhand crushing of the National Union of Mineworkers in 1984-85. If you could not get strength from the present, summon it instead from the memory of the dead, of those who had suffered and struggled unsuccessfully.

${ }^{13}$ See http://www.mediamatters.co.uk/kcurrie.htm (accessed May 12, 2016). 
One of the most famous, in recent years, of these symbols of historic defeat, can be found near the site where Lenin lived during his London exile, in the form of an apartment block commissioned by the London Borough of Finsbury, known as 'Bevin Court'. This was designed in 1948 by the Soviet émigré, committed Communist and Modernist architect Berthold Lubetkin and his group Tecton, to complement a memorial to Lenin himself, which Lubetkin also designed. Together, they formed a distinctively socialistic ensemble. The block of council flats was centred around an exceptionally dramatic staircase, the obvious public fulcrum around which the building was intended to revolve; a Picasso-esque mural of London scenes by Peter Yates was placed by the entrance. But next to this, on the Victorian square that had been partly preserved, was an abstracted frame, reminding the visitor that Lenin had lived on the site. Inside was a mass-produced bust of Lenin, chosen by Lubetkin so that it could be easily replaced in case of vandalism. What actually saw its removal was the Cold War, when naming a block of flats after Lenin was considered politically unwise. Changing only two letters, the building became Bevin Court, after the right-wing Labour foreign secretary, NATO founder and former trade union leader Ernest Bevin. The symbolism of this, in the creation of a centre-left post-war consensus out of the radical instability at the end of the Second World War, should not be underestimated..$^{14}$ Persistent urban myth has it that Lubetkin

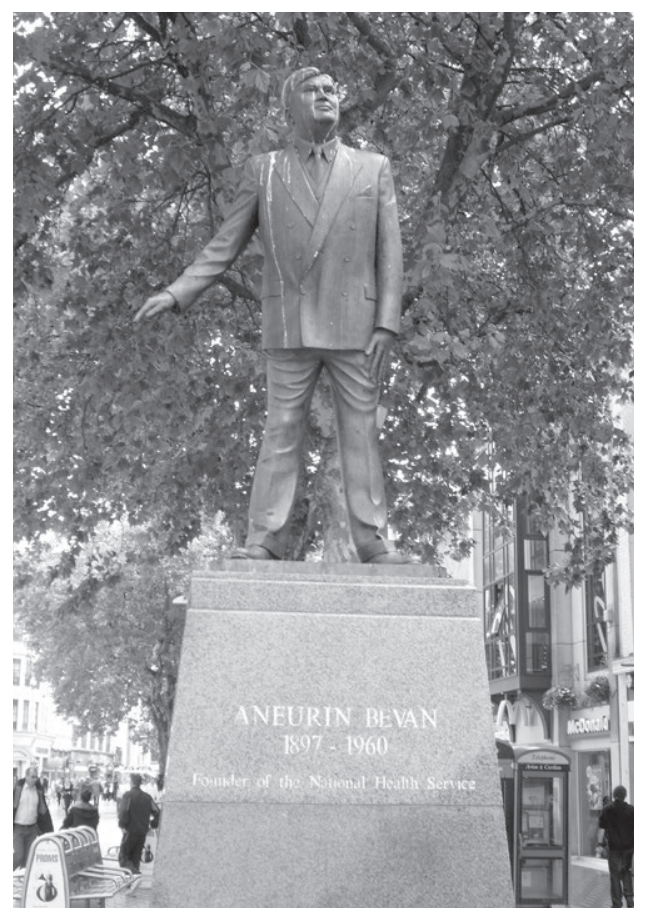

Picture 8: Aneurin Bevan Statue, Cardiff, taken by author, June 2012

https://www.flickr.com/

photos/8971770@,N06/5913279467/in/ album-72157627141542304/

${ }^{14}$ Most information here comes from John Allan's Lubetkin and the Tradition of Progress (London: Merrell, 2002). 
buried the memorial to Lenin under the staircase, which has since become one of the emblems of modern architecture in Britain.

\section{REMEMBERING THE FATHERS OF THE WELFARE STATE}

So far we have dealt largely with the failed revolutionaries of the Communist tradition, but this begs the question as to whether the Labour Party itself ever managed to create some sort of memorialising for its own existence. Founded in the 1900s through the unification of the explicitly socialist Independent Labour Party (ILP), the middle class statists of the Fabian Society and the trade unions, otherwise still committed to some form of Liberalism, the Labour Party has had some electoral success, governing for around a third of the last hundred years, and although otherwise mostly eclipsed by the Conservative Party, it was pivotal to the creation of an extensive, universal welfare state between 1945 and 1951. Its usual (although not unshakeable) tendency to political conformism means it is hardly likely to make monuments to itself, which would suggest an arrogance and aspiration to hegemony the Party has seldom shared. However, there is a small memorial space at the site of the Independent Labour Party's foundation, in the West Yorkshire industrial city of Bradford..$^{15}$ On the arterial Leeds Road, there is a bright mural of workers marching with picturesque Victorian trade union banners (this less permanent form of urban theatre is one of the better known forms of socialist memorial art, celebrated in recent years by the artist Jeremy Deller. Beneath them is the antiquated slogan 'there is no weal save Commonweal', an ILP slogan of the 1890s. This mural is a 1993 copy of a 1893 poster, slightly altered to serve its memorial function. Beneath it, is a sculpture by the local artist Terry Hamill, 'Untitled', of 1992, a heavy, abstracted, clumsy sandstone figure which appears to be rising from its slumber underneath the image of the proud, marching workers. It appears as an uncomfortably pessimistic image of the state of working class power in the 1990s.

This is exceptional, much as the ILP was always more radical than the mainstream of the Labour Party. More typical is the incredibly literal

\footnotetext{
${ }^{15}$ For an account of Bradford's centrality to the Independent Labour Party, see E. P. Thompson, "Homage to Tom Maguire". In Making History. New York: The New Press, 1994:23-65.
} 
bronze figure of one of Labour's more electorally successful leaders, Harold Wilson, in his West Yorkshire home of Huddersfield, sculpted by Ian Walters and unveiled in 1999 by Tony Blair. As evidence of the sort of antiquarian literalism expected from public art in the 1990s, it was criticised at the time for not featuring Wilson's 'famous pipe'. ${ }^{16}$ Something similar can be found in the form of the bronze statue of the Labour politician Aneurin Bevan in the Welsh capital of Cardiff, sculpted by Robert Thomas in 1987. It is as cartoonishly over-detailed as the statue of Wilson, and Bevan's floppy fringe is often used as a latrine by pigeons. More interesting is the legend on the red granite plinth underneath: 'founder of the National Health Service'. The totally socialised (until recently) and free National Health Service was and is the most lasting achievement of the Labour left, forced through against heavy opposition in the late 1940s, and taking the overwhelming majority of health care in Britain out of the hands of the private sector. Bevan, a former Miner from South Wales, cemented his position as the hero of the left when heroic failure followed heroic success, resigning from the Cabinet when prescription charges were imposed over his objections, and failing to shift Labour to the left as they moved into Opposition in the 1950s.

The Bevan statue's prosaic realism is not shared by the Aneurin Bevan Memorial Stones, which were erected in 1972 outside the small South Wales industrial town of Ebbw Vale. This artwork consists of four megaliths on a hill where Bevan used to speak to his constituents. The central stone 'represents' Bevan, and three around represent the towns of Tredegar, Ebbw Vale and Rhymney; that makes it sound much more straightforwardly monumental than it actually is. Without being informed by the small plaque on the hill, you would assume this was a stone circle, an actual neolithic burial or cult site, something which is not particularly unusual in the mountainous areas of Britain, and which is particularly present in the stereotypical, mythic history of Wales, Celtic descendants of the Druids, the purported pagan priestly caste who allegedly built Stonehenge (but almost certainly didn't). This description makes the Bevan Memorial Stones sound kitsch, a representation of 'Nye' Bevan as a sort of Merlin of the Miners,

16 "Pipeless Wilson immortalised in bronze". 1999. BBC News, July 9. http://news.bbc. co.uk/1/hi/uk_politics/390348.stm (accessed May 12, 2016). 

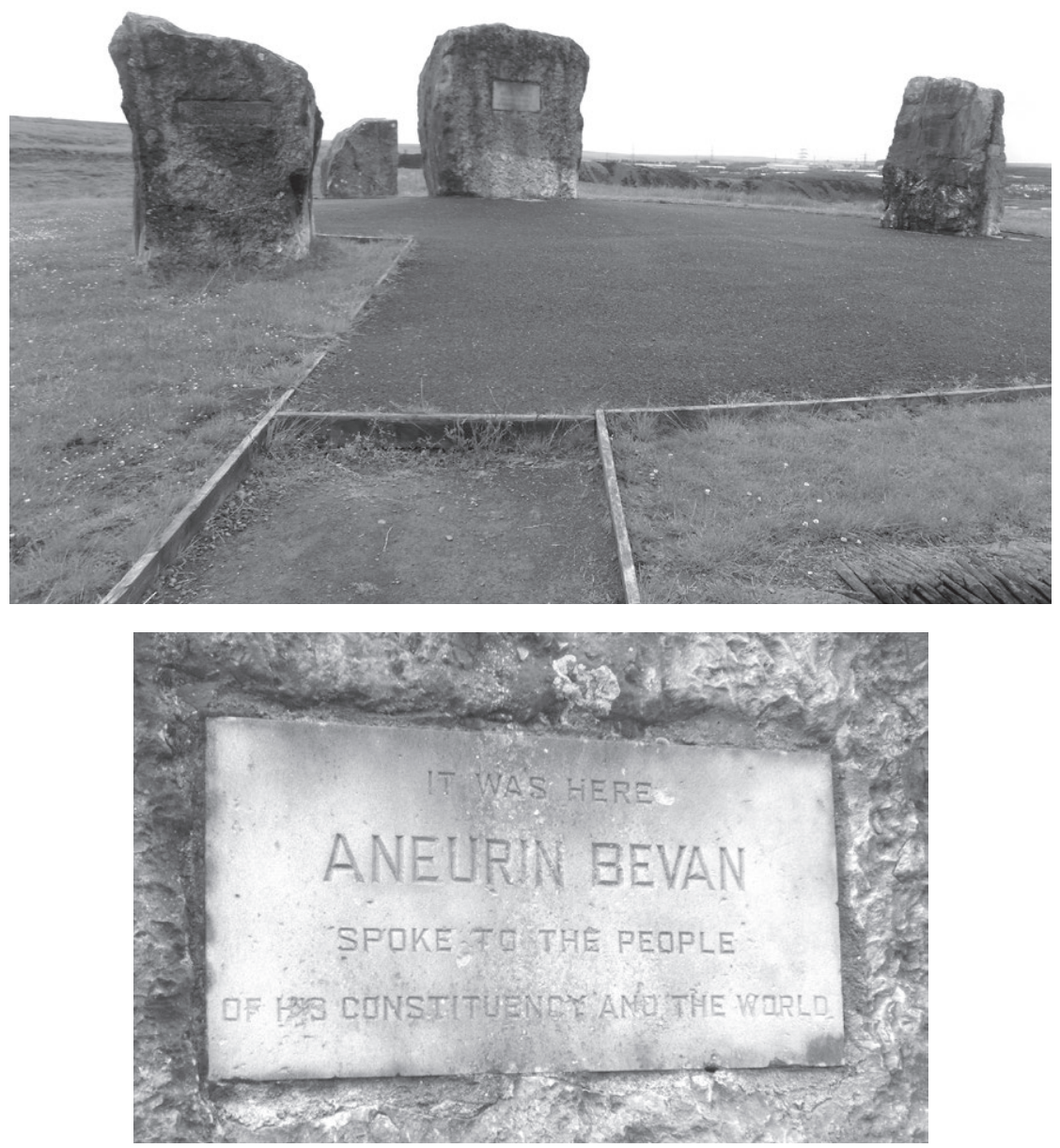

Picture 9: 'Bevan Stones', Tredegar, taken by author, June 2012 https://www:flickr.com/photos/8971770@N06/5919591809/in/album-72157627156344834/

speaking from the hill to the assembled villagers. Actually, the memorial is stranger and less bathetic than that implies; their semi-industrial, semi-rural setting and their abstraction makes them much more powerful and strange than the clumsy norm for leftwing memorialising in Britain, an image of age-old, ancient struggle without antiquarianism. 


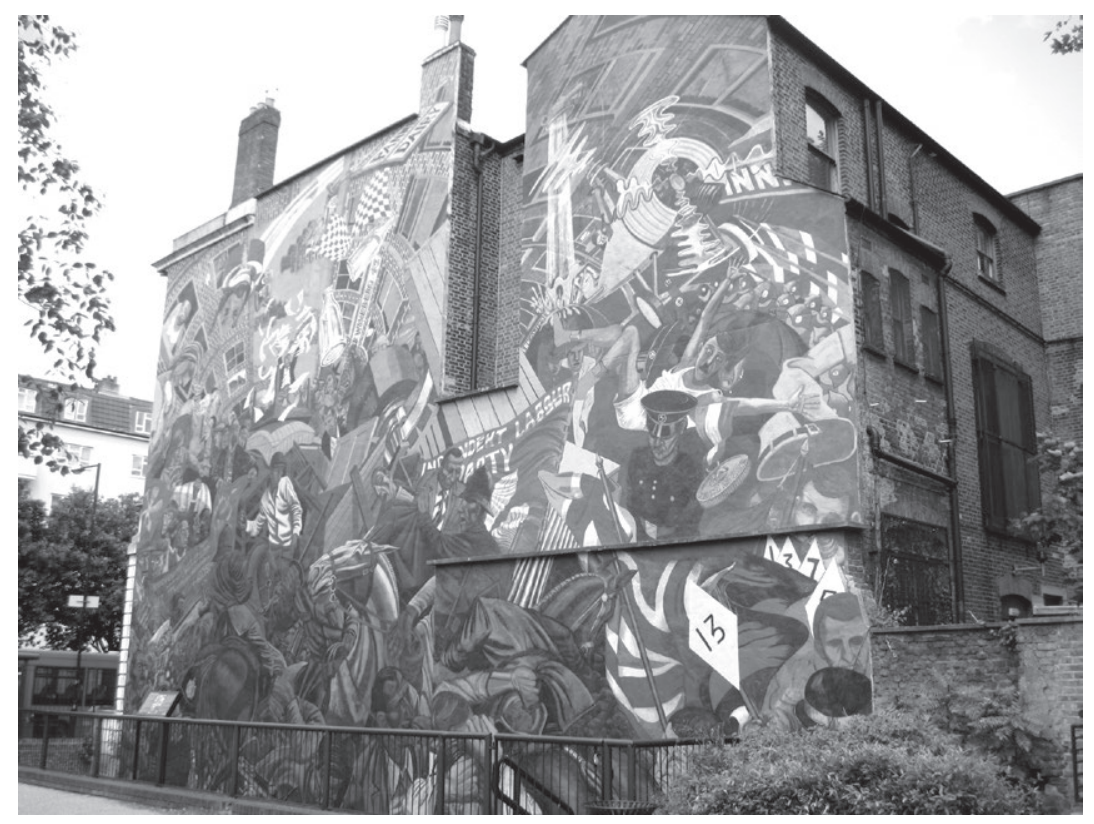

Picture 10: Cable Street Mural, London, source:

https://en.wikipedia.org/wiki/Cable Street_Mural\#/media/File:CableStreetMural.jpg

\section{MONUMENTS TO THE PRESENT}

The last major wave of socialist memorial art came in the 1980s, at the hands of the Greater London Council (under a radical leadership between 1980 and 1986) and the 'New Left' groups that had emerged along with it, to shift - with varying levels of success - an apparently moribund Labour Party to something more radical. The GLC, commissioning on its own work for the gable-ends of housing estates, Victorian high streets and empty sites, along with the similar work of more autonomous groups like Greenwich Mural Workshop, ${ }^{17}$ produced for a few years in the mid-1980s a dizzying quantity

${ }^{17}$ The 'loony left' period, as it was derisively known, in British municipal socialism, is well covered in Andy Beckett's Promised You a Miracle - UK 1980-1982 (London: Penguin, 2015). For a good recent engagement with the murals of the era, see Marijke Steedman and Paul Crook (eds.), Reclaim the Mural: the Politics of London Murals (London: Whitechapel Gallery, 1993) and for an account of and by one of the major protagonists, Steve Lobb, The Murals of Brian Barnes (London: Eatlatinandie Books, 2013). 
of murals, all of them in a figurative style that wasn't incredibly far from the work of Viscount Hastings, and with an accompanying ethos of 'inclusion' and 'community' - portraits of, and painterly input of, residents, was often included. Put together, this work presents a much more internationalist panorama of socialist politics, from El Salvador to nuclear war, from marches in Woolwich to street festivals in Dalston, from anti-fascist marches in Stepney to housing struggles in Charlton. This is a moment which is still rather obscure, but is responsible for at least one prominent London landmark - the semi-abstract raised fists that commemorate the International Brigades of the Spanish Civil War, placed outside of County Hall, now neighboured by one of London's major tourist attractions, the Ferris wheel of the 'London Eye', immortalising the anti-fascist volunteers whose memorials have elsewhere been removed, in ex-Communist countries such as Hungary, Poland and Ukraine, where the justice of anti-fascist struggle appears today to be somewhat questioned in official histories.

An art historian surveying this work could not fail to note its formal conservatism - nearly all the memorials, murals, mosaics and monuments we have considered here are figurative, with the exception (only then, only partial) of the Aneurin Bevan Memorial Stones. This would appear to complicate certain easy Cold War binaries, and would place the body of socialist or communist memorial art in Britain closer to the compulsory figuration of the Soviet Union between the 1930s and the 1980s, than to countries which were more comfortable with abstraction in their politicised public art, such as the Polish People's Republic or the Socialist Federal Republic of Yugoslavia. Partly, as noted, this can be traced in some respects to the formal conservatism of explicitly socialist British artists and designers, from William Morris onwards, but it may also be the fact that in many cases, what has been created is not so much the memorial of an achieved success, which can be seen as the commencement of the status quo, the foundation of a state and hence an official orthodoxy, but of an alternative which has existed in a capitalist country.

Sometimes, the response to this has been to take solace in nostalgia, a creation of a leftist version of Britain's dominant 'heritage culture' and 'retrochic'. ${ }^{18}$ This is a pervasive mood on the British left; soon before the

${ }^{18}$ For contrary arguments on this, see Raphael Samuel, Theatres of Memory (London: Verso 2014), and Patrick Wright, On Living in an Old Country (London: Verso, 1983). 
election as leader of Jeremy Corbyn, from the Tolpuddle Martyrs Festivalattending wing of the Labour Party, a T-shirt became available on the internet with the slogan 'LABOUR: I PREFER THEIR EARLY WORK'. Films such as Ken Loach's documentary The Spirit of 45 or Will and Testament, on the left-wing Labour cabinet minister Tony Benn, are part of a generalised nostalgia for the apparent certainties of the immediate postwar social democratic moment; both films make extensive use of nostalgiatriggering imagery and sound, such as 1940s documentary footage, Trade Union banners and brass bands. This, curiously, reverses the argument that socialism could not be the subject of nostalgia for not having been achieved, in arguing that in fact, the 1945-51 Labour governments were a kind of socialism in action. It is a nostalgia that lacks the element of conflict in the Ostalgie common in former Warsaw Pact countries and in the former Yugoslavia, in that the historical moment in question is treated unambiguously, seen not as a future that never arrived, but rather, one that did. For that, both share a bent towards political nostalgia through consumption.

It is arguable to what degree these monuments partake of that nostalgia. Some, such as the ILP mural in Bradford, or the various monuments to the Co-Operative movement, certainly appear to be connected to this form of leftist heritage culture, one where the perpetuation of a particular memory is not wildly different to 'keeping alive' the memory of the Wars of the Roses or the Royal Navy. It becomes another part of an oft-told 'Island Story', an episode in a history of freedom and common sense stretching from Magna Carta to the National Health Service. Other works, such as the destroyed Chartist Mural of Newport, or the less formally sophisticated, but more politically innovative works of 1980s London muralists, suggest that battles have not been won, and that a struggle is still ongoing. These are more politically interesting implications, in that they can't obviously be slotted back into a familiar narrative, or be made part of a consensual, conservative form of heritage. They can be reminders of histories which are conventionally buried or ignored, as with the image in Newport of armed insurrection and the massacre of protesters, and in the case of the 1980s murals, they are fragments of an internationalism that does not treat Britain alone, but takes a global socialist perspective - especially welcome given how much the British left's culture of memory ignores, as 
much as possible, the legacy of the British Empire. ${ }^{19}$ Internationalism and the memory of massive social discord are impulses which were clearly unacceptable in most 'real socialist' countries, which often preferred to create a form of vaguely socialistic Nation Building. It is similarly a political perspective which is not encouraged in Britain, where the left, if it appears in the national narrative at all, is domesticated and made deliberately antiquated. Because of this, the more unforgiving, unresolved aspects of these socialist artworks in a capitalist country make them both a neglected and intriguing series of experiments in alternative, yet permanent urban imagery.

\section{REFERENCES}

ACKROYD, Peter. 2000. London: A Biography. London: Chatto and Windus.

ALLAN, John. 2002. Lubetkin and the Tradition of Progress. London: Merrell.

ANDERSON, Perry. 1992. English Questions. London: Verso.

BAUMAN, Zygmunt. 2011. Socialism - the Active Utopia. Abingdon: Routledge.

BECKETT, Andy. 2015. Promised You a Miracle - UK 1980-1982. London: Penguin.

BOYM, Svetlana. 2002. The Future of Nostalgia. New York: Basic.

BUCHLI, Victor. 2000. An Archaeology of Socialism. Oxford: Berg.

COHEN, Gerald A. 2009. Why Not Socialism. Princeton: Princeton University Press.

ELLIOTT, Gregory. 1993. Labourism and the English Genius. London: Verso.

FOSTER, Dawn. 2013. "The Writing on the Wall”. New Statesman, May 16, 2013.

HALL, Stuart. 1988. The Hard Road to Renewal. London: Verso.

HATHERLEY, Owen. 2009. Militant Modernism. Winchester: Zero Books.

HATHERLEY, Owen. 2016. The Ministry of Nostalgia. London: Verso.

LOBB, Steve. 2013. The Murals of Brian Barnes. London: Eatlatinandie Books.

MACINTYRE, Stuart. 1980. Little Moscows. London: Croon Helm.

MILIBAND, Ralph. 1985. "The New Revisionism in Britain". New Left Review, vol. I/150 (March-April):5-26.

\footnotetext{
${ }^{19}$ I expand on these arguments in my The Ministry of Nostalgia (London: Verso, 2016).
} 
MORRIS, William. 2008. Useful Workv. Useless Toil. London: Penguin.

OWEN, Robert. 1991. A New View of Society and Other Writings. London: Penguin.

SAMUEL, Raphael. 2014. Theatres of Memory. London: Verso.

SCRIBNER, Charity. 2004. Requiem for Communism. Cambridge: MIT.

STEEDMAN, Marijke and Paul CROOK, eds. 2013. Reclaim the Mural: the Politics of London Murals. London: Whitechapel Gallery.

TAYLOR, Barbara. 1983. Eve and the New Jerusalem - Socialism and Feminism in the $19^{\text {th }}$ Century. London: Virago.

THERBORN, Goran. 2017. Cities of Power. London: Verso.

THOMPSON, E. P. 1982. William Morris, From Romantic to Revolutionary. Pontypool: Merlin.

THOMPSON, E. P. 1994. "Homage to Tom Maguire”. In Making History. New York: New Press, 23-65.

THOMPSON, E. P. 2008. The Poverty of Theory. New York: Monthly Review.

WRIGHT, Patrick. 1983. On Living in an Old Country. London: Verso.

YALLOP, Jacqueline. 2015. Dreamstreets - a Journey through Britain's Village Utopias. London: Random House.

\section{INTERNET SOURCES}

The Glasgow History Mural. http://www.mediamatters.co.uk/kcurrie.htm (accessed May 12, 2016).

"Pipeless Wilson immortalised in bronze". 1999. BBC News, July 9. http://news.bbc. co.uk/1/hi/uk_politics/390348.stm (accessed May 12, 2016). 
Owen Hatherley

\section{NAŠI SPOMENICI SLAVNOM PORAZU: SOCIJALISTIČKI SPOMENICI U VELIKOJ BRITANIJI}

Velika Britanija jedna je od istaknutih europskih zemalja koja nikada nije imala brojčano značajniji komunistički pokret, dok je marksizam uglavnom bio ograničen na krajnje lijevo orijentirane enklave u Walesu i Škotskoj, infiltracije u Laburističku stranku ili najčešće na akademsku zajednicu. Međutim, radnički pokret u svojim radikalnijim oblicima proizveo je brojne spomenike, memorijalne komplekse i prostore razbacane po urbanim pa čak i ruralnim sredinama Velike Britanije. Najčešće su to spomenici porazu, uzme li se u obzir odsutnost bilo kakvoga hegemonijskog socijalizma u državi. Jednako tako, neobično su figurativni u odnosu na javne skulpture karakteristične za 20. stoljeće te upućuju na donekle neočekivani tradicionalizam kakav se obično ne povezuje sa Zapadom u okviru polariteta Hladnog rata, na kojima se često temelji analiza spomeničkog stvaralaštva. Ovaj rad razmatra naracije o herojskim neuspjesima izražene u obliku mozaika, murala, skulptura i spomen-ploča u južnom Walesu, na sjeveru Engleske te u Londonu, u nastojanju da odgovori na pitanje kako izgledaju socijalistički spomenici u zemlji u kojoj socijalizam u povijesnom smislu nikad nije zaživio.

Ključne riječi: Velika Britanija, marksizam, socijaldemokracija, urbanizam, nostalgija, skulptura, arhitektura

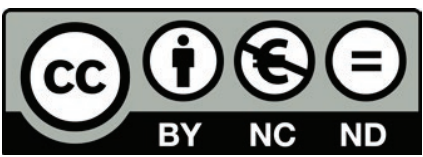

Articles published in this journal are Open Access and can be distributed under the terms and conditions of the Creative Commons license Attribution-NonCommercial-NoDerivatives 4.0 (http://creativecommons.org/licenses/by-nc-nd/4.0/) 